\title{
Faktor-Faktor yang Mempengaruhi Pendapatan Usaha Garam di Desa Oesena Kecamatan Miomafo Timur Kabupaten Timor Tengah Utara
}

Maria Atriana Domina Seran ${ }^{1}$, Simon Juan Kune ${ }^{1}$, dan Umbu Joka1*

${ }^{1}$ Program Studi Agribisnis, Fakultas Pertanian Universitas Timor, Kabupaten Timor Tengah Utara

*Correspondence author : umbujoka@unimor.ac.id

\section{Article Info}

Article history:

Received 15 June 2021

Received in revised from 27 June 2021

Accepted 31 October 2021

DOI:

https://doi.org/10.32938/ag.v6i4.1393

Keywords:

Salt

Income

Home Industry

\begin{abstract}
Abstrak
This research aims to study general descriptions and factors determining salt business income In Oesena Village, Miomafo Timur District, North Central Timor Regency. In Oesena Village, East Miomafo District, North Central Timor Regency, this research was conducted. The population and samples in this analysis were obtained using saturated sampling techniques. The overall population in this sample was 20 people who worked on salt in the Oesena Village. By measuring the sample size using the soaking sample method, all members of the population are sampled. Thus, from the explanation above, all population participants are observed, that would be 20 people. The results showed that the salt processing process in Oesena Village was divided into three stages; the filtering stage of raw material (seed salt), the cooking stage, and the filtration stage of the ripe salt. Salt marketing takes place where consumers take salt at each farmer's house at a fixed sale price. The total expense incurred by the salt farmers in Oesena Village in 2020 for the salt industry is IDR 497,057,090,00 while the total revenue is IDR 813,000,00,00 Real Salt Business Income from a reduction in total sales with a total cost so that the real salt Business Income in Oesena Village in 2020 is IDR $315,942,910,00$. Based on the capital factor t-test, the volume of production has a significant effect on income with a significant value of $0,00<0,05$ with a confidence level of $5 \%$.
\end{abstract}

\section{Pendahuluan}

Sektor industri sebagai salah satu pilar ekonomi mempunyai peranan yang sangat penting dalam menunjang perekonomian nasional di samping sektor ekonomi lainnya. Kontribusi sektor industri terhadap PDB Indonesia pada tahun 2018 mencapai 2.947,3 triliun rupiah atau 19,82\% dari total PDB nasional sebesar 14.837 triliun rupiah (BPS RI, 2019). Kontribusi tersebut perlu diikuti dengan langkah-langkah strategis dalam membangun dan mengembangkan industri. Di samping menghasilkan nilai tambah yang cukup signifikan dalam meningkatkan kesejahteraan masyarakat, sektor industri mampu mengurangi tingkat pengangguran dengan menyerap tenaga kerja sebanyak 18,25 juta orang pada tahun 2018 dengan jumlah kontribusi sebesar 14,72\% terhadap total tenaga kerja nasional (Kementerian Perindustrian RI, 2019). Berdasarkan data Kementerian Kelautan dan Perikanan (2011), wilayah laut Indonesia seluas 5.8 juta kilometer persegi . Kusumastanto (2003) menggambarkan laut Indonesia sebagai sumber daya yang menyimpan potensi . meliputi perikanan, minyak bumi, energi kelautan, dan jasa lingkungan (pariwisata, perhubungan, penetralisir limbah).

Garam merupakan salah satu hasil kekayaan laut yang bermanfaat bagi kehidupan manusia sehingga memiliki posisi strategis selain beras. Kementerian Kelautan dan Perikanan (2011) menginformasikan bahwa kebutuhan pokok konsumsi garam untuk manusia kurang lebih $4 \mathrm{~kg}$ per tahun. Kebutuhan garam nasional sebagian besar digunakan untuk konsumsi, untuk industri Chlor Alkali Plant (CAP), industri aneka pangan, pengeboran minyak, serta kebutuhan lainnya. Tahun 2020, kebutuhan garam nasional mengalami peningkatan dari perkiraan 3 juta 4,2 juta ton menjadi 4,5 juta ton, terdiri dari kebutuhan rumah tangga sebanyak 321 ribu ton, kebutuhan industri 3,4 juta ton, dan kebutuhan lainnya sebesar 398 ribu ton. Hingga saat ini Indonesia masih mengimpor garam sebanyak 2,92 juta ton pada tahun 2020; lebih besar dari kuota impor pada tahun 2019 yang mencapai 2,6 juta ton (Gambar 1).

Salah satu provinsi di Indonesia yang memiliki usaha industri garam yaitu Nusa Tenggara Timur (NTT). Provinsi NTT merupakan wilayah kepulauan yang terdiri dari 566 pulau dengan 4 pulau besar, yaitu pulau Flores, Sumba, Timor, dan Alor yang memiliki wilayah pantai dengan panjang $\pm 5.700 \mathrm{~km}$ dan memiliki potensi yang sangat besar sehingga dapat dikembangkan menjadi tempat produksi garam utama di Indonesia. Harapan ini tidak berlebihan karena wilayah 
NTT memiliki beberapa keunggulan secara fisik (alam) yaitu luas wilayah Provinsi NTT mencapai 47.349,9 kilometer persegi, dan luas perairan kurang lebih 200 ribu kilometer persegi; di luar perairan Zona Ekonomi Ekslusif Indonesia (ZEEI) dengan kadar garam air lautnya yang tinggi. Iklim dan penyinaran matahari di Provinsi NTT sangat mencukupi; bahkan cenderung panas dan kering sehingga sangat mendukung proses pembuatan garam. Garam nasional yang diproduksi pada tahun 2015 sebanyak 2,9 juta ton sementara kebutuhan hanya 2 juta ton. Pada tahun 2016, produksi sebanyak 144 ribu ton sedangkan kebutuhan sebanyak 4,1 juta ton. Tahun 2017, produksi 118,056 ton atau setara 3,7\% dari target 3,2 juta ton, memaksa pemerintah mengimpor garam sebanyak 2,5 juta ton. Sedangkan di tahun 2018 kuota impor garam mencapai 3,7 juta ton (Kementerian Kelautan dan Perikanan, 2020).

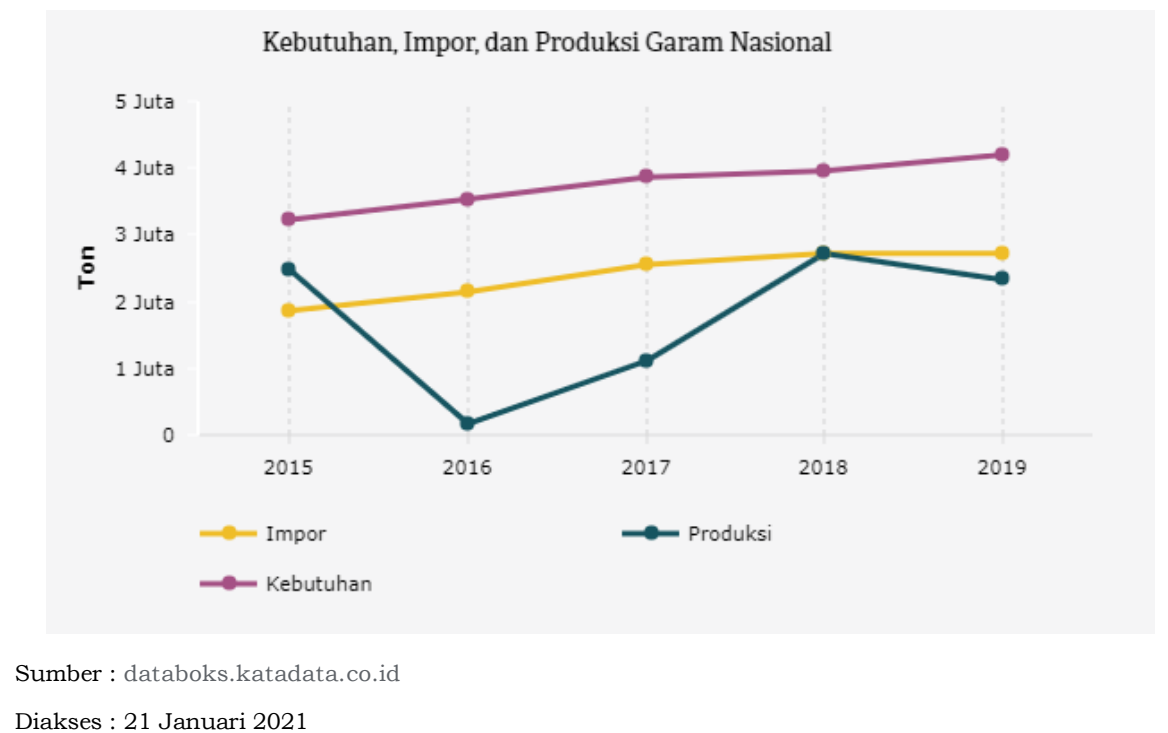

Gambar 1. Kebutuhan, impor, dan produksi garam nasional.

Kabupaten Timor Tengah Utara TTU merupakan salah satu Kabupaten di NTT yang mempunyai potensi sebagai lokasi pengembangan garam. Panjang garis pantai yang dimiliki Kabupaten TTU kurang lebih 50 kilometer dengan luas wilayah laut kurang lebih 950 kilometer persegi beserta aneka potensi yang terdapat di dalamnya seperti ikan, rumput laut,dan lain sebagainya. Tambak garam di wilayah Kabupaten TTU pada tahun 2016 mampu memproduksi sebanyak 770 ton garam mentah (BPS Kabupaten TTU, 2018). Daerah-daerah yang berada di pesisir pantai mempunyai potensi yang bagus untuk pengembangan produksi garam; hal ini dikarenakan kondisi iklim dan cuaca yang cenderung panas sehingga mendukung daerah tersebut dalam menghasilkan garam. Kesadaran masyarakat terkait potensi dalam usaha industri garam masih rendah dan lebih memilih untuk mengelola lahan kering menjadi lahan pertanian. Daerah pesisir pantai yang ada di TTU adalah Wini dan Oesoko yang merupakan daerah penghasil garam karena dekat dengan laut. Walaupun penghasil garam banyak di daerah pesisir Pantai, tidak menutupi kemungkinan untuk mengusahakan garam di tempat yang jauh dari pesisir pantai.

Kecamatan Miomaffo Timur adalah salah satu kecamatan yang terletak di Kabupaten Timor Tengah Utara. Pendapatan usaha garam di Kecamatan Miomaffo Timur pada tahun 2014 dengan target kinerja 1021,4 ha namun hanya mampu direalisasikan seluas 260,45 ha dengan pencapaian kinerja usaha garam sebesar 25,78\%. Desa Oesena adalah salah satu desa yang terletak di Kecamatan Miomafo Timur dan merupakan salah satu desa penghasil usaha garam yang masih mempraktikan usaha garam secara konvensional yang bercirikan : penguasaan teknologi yang rendah, pemilikan modal yang lemah, serta keterampilan manajemen yang sangat terbatas (BPS Kab. TTU, 2019). 
Kegiatan produksi merupakan bentuk respon terhadap kegiatan konsumsi. Produksi adalah kegiatan menciptakan suatu barang atau jasa sementara konsumsi adalah kegiatan memakai atau memanfaatkan hasil produk baik secara langsung maupun tidak langsung dengan tujuan memenuhi kebutuhan hidup. Jumlah produksi garam di Desa Oesena selama 3 tahun berturutturut yaitu tahun 2017 produksi sebanyak $399.000 \mathrm{~kg}$, tahun 2018 produksi sebanyak 371.000 $\mathrm{kg}$ dan tahun 2019 produksi sebanyak $243.900 \mathrm{~kg}$. Pengembangan produksi garam yang dilakukan selama tahun 2017-2019 selalu mengalami penurunan. Hal ini tentunya berpengaruh pada penurunan pendapatan yang diperoleh petani garam. Tujuan dari penelitian ini adalah untuk mengetahui gambaran umum dan faktor-faktor yang mempengaruhi pendapatan usaha garam di Desa Oesena Kecamatan Miomaffo Timur, Kabupaten Timor Tengah Utara (BPS Kabupaten TTU, 2020).

\section{Metode Penelitian}

\section{Tempat dan Waktu Penelitian}

Penelitian ini dilaksanakan di Desa Oesena, Kecamatan Miomafo Timur, Kabupaten Timor Tengah Utara selama 3 bulan (Agustus-Oktober tahun 2020). Desa Oesena merupakan salah satu desa penghasil Garam di Kecamatan Miomafo Timur.

Metode Penelitian dan Pengambilan Sampel

Teknik pengambilan sampel yang digunakan dalam penelitian ini adalah pengambilan sampel jenuh atau secara sensus (Sugiyono, 2005). Jumlah populasi dalam penelitian ini adalah 20 orang pelaku usaha garam di Desa Oesena. Pengukuran sampel dilakukan dengan menggunakan teknik sampel jenuh di mana semua anggota populasi dijadikan sebagai sampel sehingga seluruh anggota populasi diteliti.

\section{Metode Pengumpulan Data}

Data yang dikumpulkan dalam penelitian ini meliputi data primer dan data sekunder. Sugiyono (2005) menjelaskan bahwa data primer diperoleh secara langsung melalui wawancara bantuan daftar pertayaan (kuesioner) yang telah disampaikan sebelumnya yang berhubungan dengan penelitian ini. Selanjutnya data sekunder yang dibutuhkan diperoleh dari literatur yang relevan seperti buku-buku, jurnal penelitian dari internet, dan laporan-laporan yang berhubung dengan penelitian ini; didukung data dari lembaga pemerintahan dan Badan Pusat Statistik Kabupaten TTU.

\section{Teknik Analisis Data}

Tujuan pertama didekati dengan analisis deskriptif. Sugiyono (2005) menyatakan bahwa metode deskriptif adalah salah satu metode yang digunakan untuk menggambarkan atau menganalisis suatu hasil penelitian tetapi tidak digunakan untuk membuat kesimpulan yang lebih luas. Data yang digunakan merupakan data cross section, yang diambil pada selang bulan Agustus-Oktober 2020.

Analisis kuantitatif digunakan guna menjawab tujuan kedua, terkait faktor yang mempengaruhi pendapatan usaha garam di Desa Oesena. Pengaruh faktor modal, tenaga kerja , tingkat pendidikan, umur, dan jumlah produksi terhadap pendapatan usaha garam diestimasi dengan analisis persamaan Regresi Linear Berganda. Persamaan regresi linear berganda yang digunakan merujuk pada Joka et al., (2019) yaitu sebagai berikut:

Dimana :

$$
\text { Ln } Y=\beta_{0}+\beta 1 \text { LnUmur }+\beta_{2} \text { LnPend }+\beta_{3} \operatorname{LnModal}+\beta_{4} \operatorname{LnTK}+B_{5} \operatorname{LnProd}+e i
$$

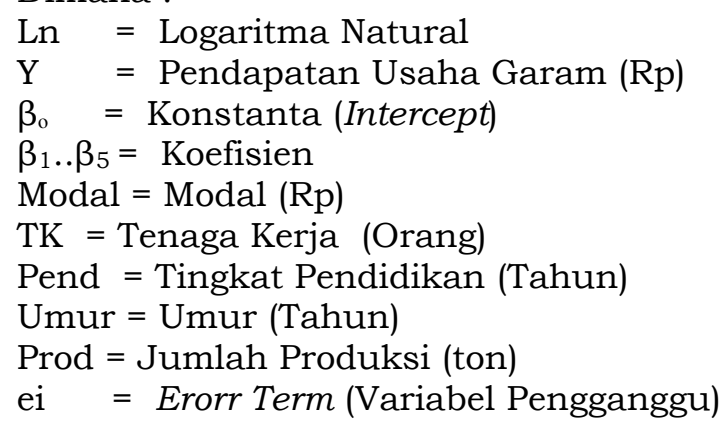




\section{Hasil dan Pembahasan Identitas Responden}

Identitas responden dalam penelitian ini mencakup umur, jumlah tanggungan keluarga, tingkat pendidikan, tenaga kerja, dan pengalaman kerja. Usia responden umumnya berada pada kisaran 31-40 berjumlah 14 orang $(70 \%)$ dan 51-60 berjumlah 6 orang dengan (30\%). Tingkat pendidikan responden terbanyak pada tingkat pendidikan SD sebanyak 14 orang $(70 \%)$. Tenaga kerja berada pada kisaran 2-3 orang bagi 19 orang responden yang berusaha garam dengan presentase 95\% dan satu responden yang menggunakan tenaga kerja sebanyak 4 orang. Selanjutnya, pengalaman kerja berada pada kisaran 4-20 tahun bagi 14 orang responden $(70 \%)$ dan 6 responden (30\%) yang lebih dari 20 tahun berusaha garam.

\section{Analisis Pendapatan \\ Biaya Usaha Garam}

Biaya tetap terdiri dari biaya penyusutan, pajak, dan penampung air. Total biaya tetap dalam penelitian ini sebesar Rp.15.002.090,00. Biaya variabel terdiri dari transportasi, bahan baku (biji garam mentah), air, kayu bakar, seng licin, transportasi pemasaran, dan biaya konsumsi. Total biaya variabel sebesar Rp. 482.055.000,00. Total biaya sebesar Rp. 497.057.090,00, selaras dengan penelitian Hanik \& Mutmainah (2020) yang menggambarkan biaya usaha garam di Kabupaten Pamekasan tergolong kecil jika dibandingkan dengan usaha pengolahan sektor kelautan dan perikanan lainnya.

\section{Produksi dan Penerimaan Usaha Garam di Desa Oesena}

Usaha garam di Desa Oesena pada bulan Agustus - Oktober 2020 memproduksi sebanyak 8.130 karung $(405.500 \mathrm{~kg})$. Garam dijual kepada pelanggan dengan harga jual sebesar Rp $2.000,00 / \mathrm{kg}$, lebih rendah dari harga garam nasional yang berkisar Rp. 4.500,00/kg. Total penerimaan dari hasil penjualan garam sebesar Rp 813.000.000,00.

\section{Pendapatan Usaha Garam di Desa Oesena}

Pendapatan yang diperoleh petani garam di Desa Oesena merupakan hasil pengurangan dari total penerimaan dengan total biaya produksi. Total pendapatan usaha garam di Desa Oesena pada tahun 2020 adalah sebesar Rp 315.942.910,00.

\section{Koefisien Determinasi}

Tabel 1. Uji Koefisien Determinasi $\left(R^{2}\right)$

\begin{tabular}{ccccc}
\hline Model & $\mathrm{R}$ & $\mathrm{R}$ Square & Adjusted R Square & Std. Error of the Estimate \\
\hline 1 & $.983^{\mathrm{a}}$ & .966 & .954 & .308 \\
\hline \multicolumn{2}{l}{ Sumber : Data diolah dengan SPSS versi $16(2020)$}
\end{tabular}

Berdasarkan hasil analisis regresi linier berganda menunjukkan variabel independen Umur (Umur), Tingkat Pendidikan (Pend), Modal (Modal), Tenaga Kerja (TK), dan Jumlah Produksi (Prod) memiliki pengaruh sebesar $95,4 \%$ terhadap peningkatan maupun penurunan produksi, sedangkan sisanya sebesar $6 \%$ dijelaskan oleh faktor lain diluar faktor yang diteliti.

\section{Uji Simultan atau Secara Bersama (Uji F)}

Berdasarkan uji $\mathrm{F}$ diketahui bahwa nilai $\mathrm{F}$ hitung $=79,183$. Hasil analisis data menunjukkan bahwa $\mathrm{F}$ hitung 79,183 > dari $\mathrm{F}$ tabel 3,11 sehingga dapat dikatakan bahwa variabel bebas atau independen yang meliputi umur, tingkat pendidikan, modal, tenaga kerja, dan jumlah produksi secara bersama-sama memiliki pengaruh yang signifikan terhadap pendapatan usaha garam.

\section{Uji T (Secara Parsial)}

Tabel 2. Hasil pengujian secara parsial

\begin{tabular}{lcl}
\hline Model & Koefisien & Sig \\
\hline Constant) & 32.139 & 0.000 \\
LnUmur & 0.032 & 0.921 \\
LnT. Pend & 0.117 & 0.559 \\
LnModal & -.3 .259 & $0.000^{*}$ \\
LnT. Kerja & 0.167 & 0.661 \\
LnJuml. Prod & 4.178 & $0.000^{*}$ \\
\hline
\end{tabular}

Sumber : Data diolah dengan SPSS versi 16 (2020)

*Signifikan pada $\mathrm{a}=0,05$ 
Hasil persamaan analisis regresinya adalah sebagai berikut:

$$
\operatorname{LnY}=32,139+0,032 \text { Umur }+0,117 \text { Pend }-3,259 \text { Modal }+0,167 \mathrm{TK}+4,178 \text { Prod }
$$

Dari tabel 2 diketahui nilai signifikan 0,921 > 0,05. Maka dapat dikatakan bahwa variabel umur berpengaruh positif namun tidak signifikan terhadap pendapatan (Y). Artinya, jika umur bertambah maka pendapatan akan semakin meningkat karena dengan penambahan umur $1 \%$ akan meningkatkan pendapatan sebesar 0,032\%. Dapat dikatakan bahwa umur petani garam tidak memiliki pengaruh yang signifikan terhadap pendapatan usaha garam. Hal ini disebabkan semakin besar atau semakin tua umur petani maka akan mempengaruhi tenaga petani sehingga produktivitas petani semakin menurun dan usaha garam kurang diminati oleh generasi muda selaras dengan temuan Widiarto et al., (2013).

Secara parsial, hasil perhitungan menunjukkan signifikan 0,559 >0,05 sehingga faktor tingkat pendidikan tidak berpengaruh signifikan terhadap pendapatan (Y). Pendidikan responden di lokasi penelitian masih tergolong rendah dengan pendekatan jenjang pendidikan yang ditempuh, terlihat dari persentase tingkat pendidikan responden terbanyak yang berada pada tingkat pendidikan sekolah dasar sehingga menyebabkan rendahnya produktifitas tenaga kerja dan manajemen di sektor industri. Artinya bahwa setiap penambahan $1 \%$ tingkat pendidikan akan meningkatkan pendapatan sebesar 0,117\%. Usaha garam di Desa Oesena masih berpatokan pada pengetahuan dan pengalaman yang diperoleh secara turun-temurun, belum mendapat sentuhan inovasi dan teknologi sehingga produktifitasnya menjadi rendah (Widiarto et al., 2013)

Variabel modal berpengaruh signifikan terhadap pendapatan $(\mathrm{Y})$. Hal ini dilihat dari nilai $\mathrm{t}$ hitung dan $\mathrm{t}$ tabel, dimana nila $\mathrm{t}$ hitung $-7,711<\mathrm{t}$ tabel 1,76131 dengan nilai signifikan $0,00<$ 0,05 . Hal ini menunjukkan bahwa semakin banyak modal yang digunakan dalam melakukan usaha garam maka cenderung menurunkan pendapatan. Artinya setiap penambahan $1 \%$ modal akan menurunkan pendapatan sebesar $-7.711 \%$. Hal ini disebabkan karena petani garam umumnya sudah puas menjalankan usahanya dengan modal terbatas sehingga penambahan modal dianggap tidak efisien (Widiarto et al., 2013). Dapat disimpulkan bahwa secara ekonomis usaha tersebut belum dilakukan secara efisien selaras dengan temuan Zakki \& Sayidah (2015) serta Langga \& Hyronimus (2021) yang menjelaskan usaha garam belum efisien dalam penggunaan modal dengan mengadakan alat yang lebih modern demi peningkatan kuantitas serta kualitas produk.

Variabel tenaga kerja tidak berpengaruh signifikan terhadap pendapatan usaha garam dimana nilai t hitung $0,448<\mathrm{t}$ tabel 1,76131 dengan nilai signifikan 0,661 > 0,05. Semakin bertambahnya tenaga kerja diharapkan dapat meningkatkan pendapatan, tetapi tenaga kerja kurang didukung pendidikan/pengetahuan serta keterampilan manajemen yang dimiliki oleh tenaga kerja masih relatif rendah ditambah sarana produksi yang kurang memadai , serta bahan baku yang kurang berkualitas dan juga masih menggunakan alat-alat tradisional dalam proses produksi mempengaruhi pendapatan usaha garam, dimana produk yang dihasilkan kalah bersaing dengan garam dari produsen lain. Hal ini selaras dengan Hanik \& Mutmainah (2020) yang mengemukakan rendahnya produktivitas serta mutu garam merupakan indikaksi dari rendahnya kualitas sumber daya manusia (SDM).

Jumlah produksi berpengaruh signifikan terhadap pendapatan usaha garam. Hal ini dilihat dari nilai $\mathrm{t}$ hitung dan $\mathrm{t}$ tabel, dimana nilai $\mathrm{t}$ hitung 11,627 $>\mathrm{t}$ tabel 1,76131 dengan nilai signifikan $0,00<0,05$. Hal ini menunjukkan bahwa semakin bertambah jumlah produksi maka semakin meningkatkan pendapatan yang diperoleh. Artinya, dengan penambahan $1 \%$ produksi akan meningkatkan pendapatan sebesar $4,178 \%$. Dengan demikian, hipotesis H1 diterima dan HO ditolak sehingga hipotesis yang berbunyi terdapat pengaruh variabel jumlah produksi terhadap pendapatan secara parsial diterima. Hasil penelitian ini seturut dengan penelitian Ruhaniyah (2014) dan Sahid (2015) yang menunjukkan bahwa jumlah produksi berpengaruh nyata pada pendapatan usaha garam.

\section{Simpulan}

Produksi garam yang dihasilkan oleh petani di Desa Oesena Kecamatan Miomafo Timur dengan produksi yang dilakukan pada tahun 2020 mencapai $243.900 \mathrm{~kg}$. Proses produksi garam yang dilakukan petani terbagi dalam 3 tahap yaitu tahap penyaringan bahan baku, tahap pemasakan, dan tahap penyaringan garam yang sudah masak. Pemasaran garamoleh petani masih dilaksanakan secara konvensional. Secara parsial, faktor modal dan jumlah produksi memiliki pengaruh yang signifikan terhadap pendapatan dengan nilai signifikan $0,00<0,05$. Selanjutnya, faktor umur, tingkat pendidikan, dan tenaga kerja tidak berpengaruh secara parsial terhadap pendapatan usaha garam karena nilai t hitung lebih kecil dari nilai t tabel. 


\section{Pustaka}

BPS. Kab. TTU. 2019. Kecamatan Miomaffo Timur dalam angka 2019. Kefamenanu.BPS BPS. Kab TTU . 2020. Timor Tengah Utara dalam Angka 2020. Kefamenanu. BPS

BPS. RI. 2019. Data Kontribusi Sektor Industri Terhadap Produk Domestik Bruto (PDB) 2018.

Hanik, U., \& Mutmainah, M. (2020). Analisis Kinerja Dan Kebutuhan Petani Garam Di Kabupaten Pamekasan Sebagai Dasar Pengembangan Desain Model Social Learning. Jurnal Sosial Ekonomi Kelautan Dan Perikanan, 15(2), 237. https://doi.org/10.15578/jsekp.v15i2.7842

Joka, U., Anggraeni, L., \& Fariyanti, A. (2019). Impact of PUAP Programs against Rice Farmer's Income in Kupang District of East Nusa Tenggara Province. Agrimor, 4(1), 13-15. https: / / doi.org/ 10.32938/ag.v4i1.624

Kementerian Kelautan dan Perikanan (KKP). 2020 . Kelautan dan Perikanan dalam Angka 2020. Pusat Data Statistik dan Informasi (Pusdatin), Kementerian Kelautan dan Perikanan, Jakarta.

2011 . Pedoman Pelaksanaan Pemberdayaan Usaha Garam Rakyat. Direktorat Pemberdayaan Masyarakat Pesisir dan Pengembangan Usaha (PMPPU) Kementerian Kelautan dan Perikanan, Jakarta.

Kementerian Perdagangan, 2019. Kebutuhan , Impor, dan Produksi garam Nasional. Kementerian Perdagangan, Jakarta.

Kementrian Perindustrian RI. 2019. Data Penyerapan Tenaga Kerja Oleh Sektor Industri 2018.

Kusumastanto, T. (2003). Pemberdayaan sumberdaya kelautan, perikanan dan perhubungan laut dalam abad XXI. Pusat Kajian Sumberdaya Pesisir dan Lautan, Institut Pertanian Bogor.

Langga, L., \& Hyronimus, H. (2021). Analisis Faktor-Faktor Hasil Produksi Yang Mempengaruhi Tingkat Pendapatan Petani Garam Pada Masyarakat Desa Paupanda Kecamatan Wewaria Kabupaten Ende. MEDIA BINA ILMIAH, 15(9), $\quad$ 5191-5198.. https:/ / doi.org/10.33758/mbi.v15i9.963

Ruhaniyah, S. (2014). Analisis pendapatan dan pola pengeluaran rumah tangga petani garam di desa lembung kecamatan galis kabupaten pamekasan (Doctoral Dissertation, University of Muhammadiyah Malang). Malang. Universitas Muhammadiyah Malang

Sahid, M. (2015). Analisis Tingkat Pendapatan Petani Garam di Desa Pangarengan Kecamatan Pangarengan Kabupaten Sampang (Doctoral Dissertation, University of Muhammadiyah Malang). Malang. Universitas Muhammadiyah Malang

Sugiyono. 2005. Metode Penelitian Pendidikan (Pendekatan Kualitatif, Kuantitatif dan $R$ \& D). Bandung: Alfabeta.

Widiarto, S. B., Hubeis, M., \& Sumantadinata, K. (2013). Efektivitas Program Pemberdayaan Usaha Garam Rakyat di Desa Losarang, Indramayu. MANAJEMEN IKM: Jurnal Manajemen Pengembangan Industri Kecil Menengah, https: / / doi.org/ 10.29244/mikm.8.2.144-154

Zakki, N., \& , S. (2015). Faktor-Faktor Yang Mempengaruhi Pendapatan Dan Kesejahteraan Petani Garam Rakyat Kawasan Pesisir Kalianget. PERFORMANCE " Jurnal Bisnis \& Akuntansi," 5(2), 66. https://doi.org/10.24929/feb.v6i1.259 